\title{
Ammonium requirements of fast-growing ephemeral macroalgae in a nutrient-enriched marine embayment (Port Phillip Bay, Australia)
}

\author{
Stuart Campbell* \\ Department of Life Sciences, Victoria University, PO Box 14428, MCMC, Victoria 8001, Australia
}

\begin{abstract}
The observed high biomass of fast-growing macroalgae in Port Phillip Bay (PPB), Australia is of concern and may represent a shift from perennial macrophytes (e.g. kelps and seagrasses) to a dominance by fast-growing macroalgae. This study examined the limiting and optimum external ammonium-nitrogen concentrations for the growth of 3 fast-growing macroalgae that dominate reefs in northern Port Phillip Bay, Australia. The relationships between growth and tissue nutrients and the capacity of these algae to assimilate, store and survive on nutrients was examined. Winter and summer experiments aimed to determine the effects of tissue nutrient status on growth responses. An absence of any seasonal variation in critical $\mathrm{N}$ thresholds and $\mathrm{N}$ subsistence quotas in any of the species examined suggests that all species are able to tolerate low $\mathrm{N}$ availability. The utilisation of $\mathrm{N}$ reserves to support non-limited growth of Hincksia sordida (Clayton) and Polysiphonia decipiens (Montagne) was about 2- to 5 -fold shorter in summer than winter, indicating potential N-limitation during summer. A high requirement for $\mathrm{N}$ by both $\mathrm{H}$. sordida and Ulva sp. means that internal $\mathrm{N}$ reserves could support reduced growth for shorter periods compared to P. decipiens. Such high demands for $\mathrm{N}$ by $H$. sordida and Ulva sp. makes these taxa susceptible to N-limitation in summer, when inputs of $\mathrm{N}$ to coastal waters are low. Elevated nutrient inputs into PPB may allow these taxa to become nutrient-sufficient and colonise larger areas of nearshore reefs.
\end{abstract}

KEY WORDS: Fast-growing macroalgae - Ammonium - Tissue nutrients · Nutrient storage · Eutrophication Resale or republication not permitted without written consent of the publisher

\section{INTRODUCTION}

Port Phillip Bay in southern Australia is a shallow marine embayment subject to nutrient inputs from sewage and catchment sources. Fast-growing macroalgae are dominant components of this nutrientenriched nearshore habitat (Light \& Woelkerling 1992). Elsewhere, eutrophication of shallow marine embayments has led to an increase in the biomass and production of fast-growing ephemeral macroalgae

\footnotetext{
*Marine Plant Ecology Group, Northern Fisheries Centre, PO Box 5396, Cairns, 4870, Australia.

E-mail: campbes@dpi.qld.gov.au
}

(Lapointe \& O'Connell 1989, Björnsater \& Wheeler 1990, Pedersen \& Borum 1996, Valiela et al. 1997). These algae compete for available nutrients (Pedersen \& Borum 1997) and are capable of replacing slowergrowing primary producers such as perennial macroalgae and seagrasses (Cambridge et al. 1984, Fujita 1985, Pedersen \& Borum 1996). The growth of these algae have generally shown higher growth rates during spring and summer than during autumn and winter (Geertz-Hansen \& Sand-Jensen 1992, Pedersen \& Borum 1996). Growth of macroalgae may also be influenced by nutrient availability irrespective of seasonal changes in temperature and light (Lavery \& McComb 1991a). The rapid uptake of nutrients by macroalgae with high biomass and long residence times may also 
influence inorganic nutrient concentrations in the water column at the expense of other species (Fujita 1985, Pedersen \& Borum 1996, 1997).

Rapid uptake and luxury accumulation of $\mathrm{N}$ have been reported for many species of macroalgae (Chapman \& Cragie 1977, Lapointe \& Tenore 1981, Pedersen \& Borum 1997). Nutrient limitation is often dependent on seasonal in situ nutrient exposure and internal nutrient reserves (Lapointe 1985, Wheeler \& Björnsäter 1992). Stored nutrients may support maximum growth for longer periods of time and may confer a competitive advantage in areas of episodic nutrient availability (Pedersen \& Borum 1996). Interspecific differences in nutrient uptake rates may be explained by differences in morphology, especially the surface: area ratio (Wallentinus 1984, Hein et al. 1995). Nutrient requirements of macroalgae may also vary significantly with light, temperature and relative growth rates (Sfriso 1995).

Studies on nutrient requirements of macroalgae have largely focussed on differences in nutrient requirements between fast- and slow-growing taxa (Fujita 1985, Pedersen \& Borum 1996), whilst few studies have examined seasonal differences in nutrient requirements of fast-growing macroalgae (Hurd \& Dring 1990, Lavery \& McComb 1991a,b, Lohman \& Priscu 1992). It can be difficult to extrapolate findings on growth of macroalgae from culture experiments, where algae receive pulsed $\mathrm{N}$-concentrations, to field situations where nutrients are in continual supply, because nutrients may be sufficiently available for growth demands at low concentrations (Larned \& Stimson 1996, Schaffelke \& Klumpp 1998). The use of experimental pulsed concentrations may, however, have relevance to field situations when pulses of nutrients are supplied to nearshore waters from sewage outfalls or other point-sources.

The aim of this study was to examine the relationships between growth and tissue nutrient concentrations in 3 species of fast-growing macroalgae in a shallow marine embayment in Port Phillip Bay, Victoria, Australia. The species examined were the filamentous phaeophyte Hincksia sordida (Clayton), the filamentous rhodophyte Polysiphonia decipiens Montagne and the sheet-like chlorophyte Ulva sp. All algae are dominant taxa in nearshore reef areas, and this paper aims to characterise their $\mathrm{N}$ requirements, $\mathrm{N}$ storage capacities, and growth patterns in relation to internal nutrient reserves and previous nutritional history.

\section{METHODS}

Sample and collection preparation. Whole thalli of Hincksia sordida (Clayton), Polysiphonia decipiens
Montagne and Ulva sp. were collected during winter (June 1995 to August 1995) and summer (January and February 1996) from a site in Port Phillip Bay, at $3 \mathrm{~m}$ depth, approximately $500 \mathrm{~m}$ from shore. Plants were collected by SCUBA divers and kept at ambient temperature during transport to the laboratory.

Nutrient-enrichment experiments. Approximately $5 \mathrm{~g}$ (fresh weight) of plant material was washed in filtered $(0.2 \mu \mathrm{m})$ seawater in the laboratory to remove sediment and epiphytic algae. Pieces of tissue were excised into portions on the day of collection and maintained overnight in aerated natural seawater in $20 \mathrm{l}$ aquaria at $15^{\circ} \mathrm{C}$, under a downwelling photo-flux density of 150 to $200 \mathrm{mmol} \mathrm{m}^{-2} \mathrm{~s}^{-1}$ (36 W 'cool white' fluorescent tubes) and a 12:12 h light:dark cycle. Photosynthesis-irradiance curves for each species showed that the photosynthesis of each species was saturated at $<150 \mu \mathrm{mol} \mathrm{m}{ }^{-2} \mathrm{~s}^{-1}$ (S.C. unpubl. data).

Experiments designed to investigate the relationship between macroalgal growth and tissue $\mathrm{N}$ over a range of ammonium-N concentrations were set up under the above conditions. Four replicate plants (each $2 \mathrm{~g}$ fresh weight) of Hincksia sordida, Polysiphonia decipiens and Ulva sp. were placed in separate 41 aquaria on the day after collection. This achieved initial dry weight to volume ratios of 0.04 to 0.06 , enabling maintenance of optimal productivity rates (Littler 1979) and providing sufficient material for tissue-nutrient analysis. Each of the 4 replicates were subjected to 5 ammonium-N treatments $(<0.4,3.6,7.1,14.2,28.5 \mu \mathrm{M})(20$ aquaria per species), with all other physico-chemical parameters kept constant. The ammonium concentrations used were within the range of inorganic nitrogen concentrations $(<1$ to $30 \mu \mathrm{M})$ recorded in nearshore waters of Port Phillip Bay subject to sewage derived nutrient inputs (Campbell 1999). Experiments were performed on separate occasions for each species during July and August 1995 and January and February 1996, when ambient bottom water temperatures were 10 to $13^{\circ} \mathrm{C}$ and 17 to $20^{\circ} \mathrm{C}$ respectively. In situ water-column nutrient concentrations ranged from 20 to $28 \mu \mathrm{M} \mathrm{NH} \mathrm{NH}_{4}-\mathrm{N}$ and 10 to $15 \mu \mathrm{M} \mathrm{PO}_{4}$-P during July and August 1995 and from 0 to $2 \mu \mathrm{M} \mathrm{NH}_{4}-\mathrm{N}$ and 10 to $15 \mu \mathrm{M} \mathrm{PO}_{4}-\mathrm{P}$ during January and February 1996.

Nitrogen was added to the cultures as $\mathrm{NH}_{4} \mathrm{Cl}$, and $\mathrm{P}$ was added as $\mathrm{NaH}_{2} \mathrm{PO}_{4}$ from stock solutions. Each ammonium treatment was made up and changed every $2 \mathrm{~d}$ for the duration of the experiment (14 d). The water-column concentrations of ammonium-N and phosphate-P were measured at the start and finish of each 2 day period. To prevent $\mathrm{C}$ limitation, carbon was added by additions of $\mathrm{NaHCO}_{3}$ to concentrations of $3 \mathrm{mM}$ DIC. The $\mathrm{pH}$ of all cultures was monitored daily and kept at 8.1 to 8.3. To account for the seasonal effects of nutritional history on growth and avoid other 
seasonal cues, the cultures were maintained under constant saturating photosynthetic photon-flux density (200 $\mu \mathrm{mol} \mathrm{m} \mathrm{m}^{-2} \mathrm{~s}^{-1}$ and a 12:12 h light:dark cycle) and temperature $\left(15^{\circ} \mathrm{C}\right)$ to control for the effects of light and temperature. The aquaria were aerated to ensure water movement and gas equilibrium. After each experiment, algal material was removed from treatments for growth measurements (weighing) and sampled for tissue $\mathrm{N}$ and $\mathrm{P}$ analysis.

Growth rates. Growth was calculated from changes in fresh weight over a $14 \mathrm{~d}$ period. Plant material was trimmed and weighed at $7 \mathrm{~d}$ in order to maintain approximate biomass to water-volume ratios during the experiment.

The net growth rate $(\mu)$ was calculated from changes in fresh weight biomass after 7 and $14 \mathrm{~d}$, and represent the means of these 2 values:

$$
\mu=\left(\ln B_{t}-\ln B_{0}\right) t^{-1} 100
$$

For this equation, $B_{0}$ represents the initial and $B_{t}$ the final biomass after $t$ days in the experimental treatment. Units of net growth rate are $\% \mathrm{~d}^{-1}$.

Fresh and dry weights. Fresh weights of all plant material were determined after blotting with tissues. Dry weights were determined after drying at $70^{\circ} \mathrm{C}$ for $24 \mathrm{~h}$.

Nutrient analysis. Spectrophotometric analysis of water samples for inorganic nitrogen $\left(\mathrm{NH}_{4}-\mathrm{N}\right.$ and $\left.\mathrm{NO}_{3}-\mathrm{N}\right)$ and inorganic phosphorus $\left(\mathrm{PO}_{4}-\mathrm{P}\right)$ were undertaken using standard methods of Strickland \& Parsons (1972).

Algal samples for tissue $\mathrm{N}$ and $\mathrm{P}$ were dried, homogenised and digested in concentrated sulphuric acid $\left(\mathrm{H}_{2} \mathrm{SO}_{4}\right)$ and perchloric acid $\left(\mathrm{H}_{2} \mathrm{O}_{2}\right)$ using a modification of the method outlined by Allen (1989). After digestion, $\mathrm{N}$ and $\mathrm{P}$ concentrations were determined with a Novaspec II nutrient autoanalyser (Pharmacia) using methods of the American Public Health Association (1995). Concentrations are expressed either as mg $\mathrm{N}$ or $\mathrm{P}$ g dry $\mathrm{wt}^{-1}$.

Nitrogen growth parameters. Critical tissue-nitrogen concentrations $\left(N_{\mathrm{c}}=\right.$ tissue $\mathrm{N}$ concentration where maximum growth is possible), $\mathrm{N}$ subsistence quotas $\left(N_{\mathrm{q}}=\right.$ the tissue $\mathrm{N}$ concentration where growth is zero and the alga manages to subsist) of the 3 species were calculated according to the equations of Pedersen \& Borum (1996). The critical $N$ concentration, or $N_{c}$, was calculated from the intercept of the 2 lines represented by the maximum growth rate and the initial slope of the curve. The initial slope was approximated as the line going through the points where $\mu=0.5 \mu_{\text {max. }}$

Nitrogen storage capacity. The ability of algal species to accumulate $\mathrm{N}$ was examined by comparing the maximum tissue- $\mathrm{N}$ concentration measured during the laboratory experiments, as described by Pedersen \& Borum (1996). These parameters include: the maximum tissue $\mathrm{N}$ contents $\left(N_{\max }\right)$; the $\mathrm{N}$ pool stored in excess of the requirements for maximum growth $\left(N_{\mathrm{s}}=N_{\max }-N_{\mathrm{c}}\right)_{;}$the $\mathrm{N}$ storage capacity $\left[t_{\max }=\ln \right.$ $\left.\left(N_{\max } / N_{\mathrm{c}}\right) \mu_{\max }{ }^{-1}\right]$, defined as the duration (in days) this storage can sustain maximum algal growth without any compensatory $\mathrm{N}$ uptake from the external media; and the period of reduced growth in days $\left[t_{\text {red }}=\right.$ $\ln \left(N_{\mathrm{c}} / N_{\mathrm{q}}\right)\left(0.5 \mu_{\max }\right)^{-1}$ ] over which internal $\mathrm{N}$ pools are below the critical level $\left(N_{\text {red }}=N_{\mathrm{c}}-N_{\mathrm{q}}\right)$ (i.e. when the tissue $\mathrm{N}$ content decreased below the critical limit $\left[N_{\mathrm{C}}\right]$ until the subsistence quota $\left[N_{\mathrm{q}}\right]$ was reached).

Statistical analyses. Data were examined for heterogeneity of variance (Cochran's test) and skewness of data (residuals and outliers). Non-normal data were subjected to $\log$ transformation, $\ln (x+1)$. A Student's $t$-test was used to examine seasonal differences in field tissue-N content for each species. A 3-way ANOVA was used to examine for effects of factors, season, ammonium-nitrogen enrichment and species on the growth rates calculated after $14 \mathrm{~d}$. The significance level used was $\mathrm{p}<0.05$. Tukey's HSD test was used to make post-hoc multiple comparisons among treatment means from significant ANOVA tests.

Nitrogen growth parameters were calculated by plotting $\mu$ against the tissue $\mathrm{N}$ concentration for each sample, and fitting data to the Droop equation (Droop 1983) using non-linear least-square regression (SYSTAT Version 5.03, Systat Inc., Evanston, Illinois, USA).

$$
\mu=\mu_{\max }\left(1-N_{\mathrm{q}} / N\right)
$$

where $\mu_{\text {max }}$ is the maximum growth rate, $N_{\mathrm{q}}$ is the minimum tissue $\mathrm{N}$ concentration needed to sustain growth (the subsistence quota), and $N$ is the actual tissue concentration in the alga. The significance level of each regression is presented for each species on each graph in Fig. 2. Means and confidence intervals for $\mu_{\max }$ and $N_{\mathrm{q}}$ were derived from the non-linear regression. Confidence intervals for the critical $N$ concentrations $\left(N_{\mathrm{c}}\right)$ were derived from the error estimates of $\mu_{\text {max }}$. The computer package software SYSTAT (Version 5.03, Systat Inc., Evanston, Illinois, USA) was used for all analyses.

\section{RESULTS}

\section{Tissue-N}

Tissue-N contents for field collected Hincksia sordida, Polysiphonia decipiens and Ulva sp. are presented in Table 1; they were significantly higher $(\mathrm{p}<$ 0.05) for all species in winter than in summer. 
Table 1. Hincksia sordida, Polysiphonia decipiens and Ulva sp. Tissue-N content of macroalgae collected in winter (July and August) and summer (January and February) in Port Phillip Bay. Values are means $(\mathrm{CI}), \mathrm{n}=6$. Values in any one row with different superscript letters are significantly different at $\mathrm{p}<0.05$

\begin{tabular}{|lcc|}
\hline \multirow{2}{*}{ Species } & \multicolumn{2}{c|}{ Tissue-N $\left(\mathrm{mg} \mathrm{g}^{-1}\right.$ dry wt) } \\
\cline { 2 - 3 } & Winter & Summer \\
\hline H. sordida & $43.22^{\mathrm{a}}$ & $25.12^{\mathrm{b}}$ \\
& $(2.9)$ & $(4.9)$ \\
P. decipiens & $44.30^{\mathrm{a}}$ & $35.50^{\mathrm{b}}$ \\
& $(4.6)$ & $(2.3)$ \\
Ulva sp. & $43.78^{\mathrm{a}}$ & $28.27^{\mathrm{b}}$ \\
& $(5.2)$ & $(4.4)$ \\
\hline
\end{tabular}

\section{Growth responses to nutrients}

For all growth cultures after each 2 day enrichment period, ammonium-N was depleted in all $<0.4 \mu \mathrm{M}$ treatments and in $30 \%$ of $3.6 \mu \mathrm{M}$ replicates, across all algae examined. In all other treatments (i.e. $\geq 7.1 \mu \mathrm{M}$ ) residual ammonium- $\mathrm{N}$ was found in the culture media after $2 \mathrm{~d}$, indicating $\mathrm{N}$ sufficiency at these higher concentrations.

The mean net $\mu\left(\% \mathrm{~d}^{-1}\right)$, obtained over the $14 \mathrm{~d}$ period increased asymptotically towards $\mu_{\max }$ with increasing tissue-N content in all algae during winter (Fig. 1). Of all species, this relationship was strongest in Hincksia sordida (Clayton) during winter $\left(\mathrm{r}^{2}=0.71\right)$ and summer $\left(r^{2}=0.78\right)$. This relationship was weak for Polysiphonia decipiens in winter $\left(\mathrm{r}^{2}=0.63\right)$, but stronger in summer $\left(\mathrm{r}^{2}=0.79\right)$. Weak relationships were found for Ulva sp. in winter $\left(\mathrm{r}^{2}=0.25\right)$ and in summer $\left(\mathrm{r}^{2}=0.002\right)$.

The estimated $\mu_{\max }$ in the experiments varied seasonally for all 3 species (Table 2). There was a 2- to 3 -fold difference in maximum growth rate between species with Ulva sp. having the highest rate. During winter, $\mu_{\max }$ was lower in Polysiphonia decipiens $\left(0.049 \mathrm{~d}^{-1}\right)$ than in both Hincksia sordida $\left(0.093 \mathrm{~d}^{-1}\right)$ and Ulva sp. $\left(0.118 \mathrm{~d}^{-1}\right)$. A similar pattern was evident in summer, with a higher $\mu_{\max }$ recorded for $H$. sordida $\left(0.116 \mathrm{~d}^{-1}\right)$ than for $P$. decipiens $\left(0.088 \mathrm{~d}^{-1}\right)$. Growth of Ulva sp. in summer was negligible; data did not fit the Droop model, and therefore no $\mu_{\max }$ was calculated.

The growth of all 3 species showed enhancement in response to ammonium-N additions (Fig. 2). Growth of Hincksia sordida in summer and winter and of Polyishonia decipiens in summer increased with ammonium$\mathrm{N}$ additions from $<0.4$ to $14.2 \mu \mathrm{M}$. In winter there was no increase in growth rate in $P$. decipiens or Ulva sp. above $3.6 \mu \mathrm{M}$. In summer, Ulva sp. showed no growth enhancement with ammonium-N enrichment.
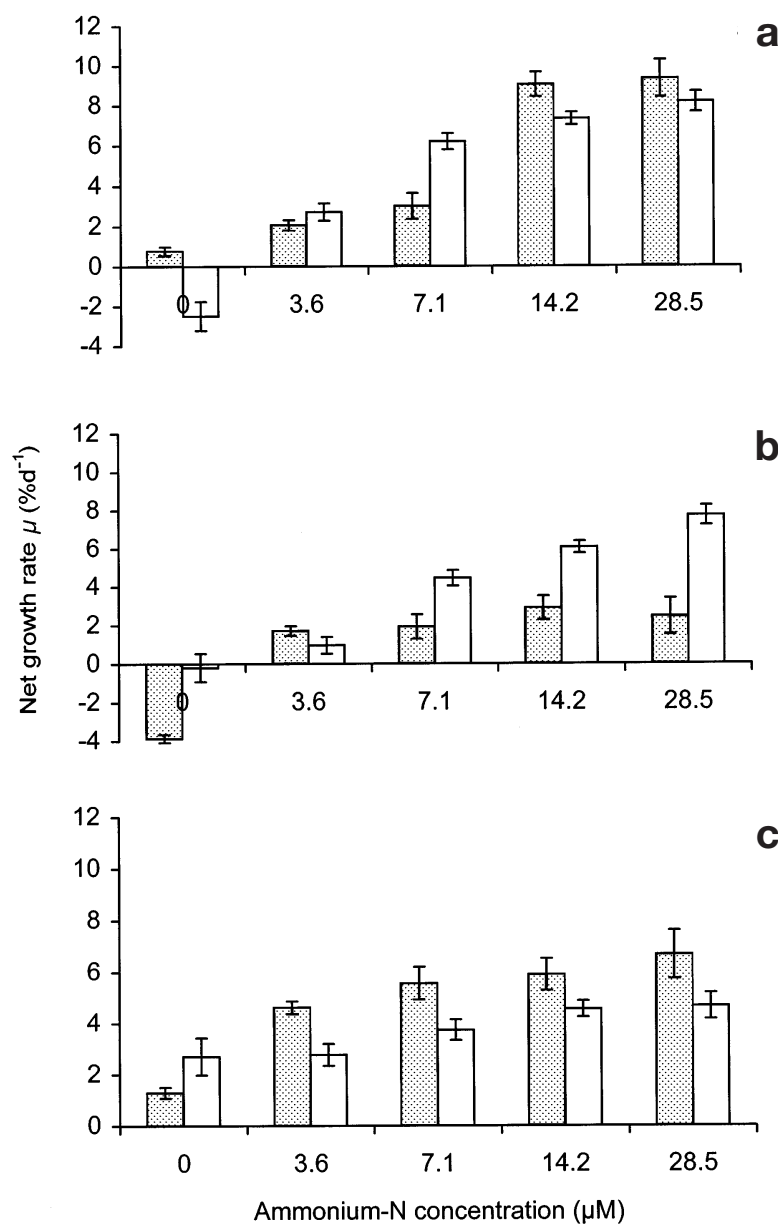

Fig. 1. (a) Hincksia sordida, (b) Polysiphonia decipiens and (c) Ulva sp. Net growth rates after exposure to ammonium-N over a $14 \mathrm{~d}$ period in winter (shaded bars) and summer (open bars). Values are means $( \pm \mathrm{SE}), \mathrm{n}=4$

A 3-way ANOVA revealed significant effects of season, ammonium concentration and species on the specific growth rates of the 3 species examined (Table 3 ). A significant 3-way interaction was due to: higher

Table 2. Hincksia sordida, Polysiphonia decipiens and Ulva sp. Maximum net growth rates $\left(\mu_{\max }\right)$, obtained from laboratory experiments. Values are means $(\mathrm{CI}), \mathrm{n}=4$. Values in any one row with different superscript letters are significantly different at $\mathrm{p}<0.05$

\begin{tabular}{|lcc|}
\hline \multirow{2}{*}{ Species } & \multicolumn{2}{c|}{$\mu_{\max }\left(\% \mathrm{~d}^{-1}\right)$} \\
\hline Hinter & Summer \\
H. sordida & $9.3^{\mathrm{a}}$ & $11.6^{\mathrm{b}}$ \\
& $(1.8)$ & $(2.1)$ \\
P. decipiens & $4.9^{\mathrm{a}}$ & $8.8^{\mathrm{b}}$ \\
Ulva sp. & $(1.4)$ & $(1.6)$ \\
& 11.8 & \\
\hline
\end{tabular}



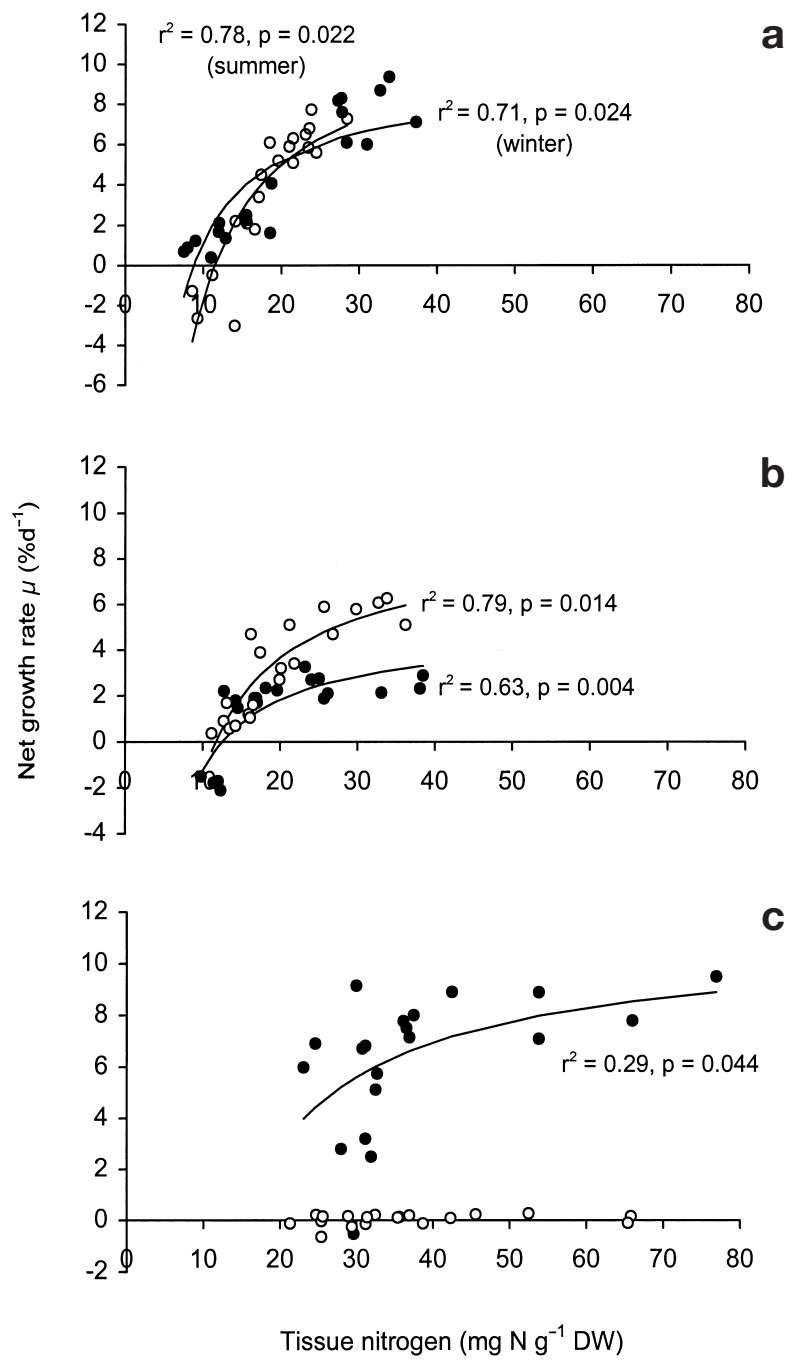

Fig. 2. (a) Hincksia sordida, (b) Polysiphonia decipiens and (c) Ulva sp. Net growth rates in relation to tissue-N content $\left(\mathrm{mg} \mathrm{N} \mathrm{g}^{-1}\right.$ dry wt) in winter (•) and summer (०) , $\mathrm{n}=20$

Table 3. Hincksia sordida, Polysiphonia decipiens and Ulva sp. Three-factor ANOVA comparing growth rates of the macroalgae after $14 \mathrm{~d}$. Factors were season (winter vs summer), $\mathrm{N}$ treatments $\left(<0.4\right.$ to $\left.28.6 \mu \mathrm{M} \mathrm{NH}_{4}{ }^{+}\right)$, and species. Data were log-transformed and fulfilled the Cochran test of homogeneity of variances

\begin{tabular}{|lrrc|}
\hline Source of variation & df & $F$ & $\mathrm{p}$ \\
\hline Season & 1 & 6.12 & 0.015 \\
Treatment & 4 & 223.38 & 0.001 \\
Species & 2 & 66.58 & 0.001 \\
Season $\times$ Treatment & 4 & 4.71 & 0.002 \\
Season $\times$ Species & 2 & 50.79 & 0.001 \\
Species $\times$ Season & 8 & 15.97 & 0.001 \\
Season $\times$ Species $\times$ Treatment & 8 & 13.37 & 0.001 \\
Error & 90 & & \\
\hline
\end{tabular}

growth rates at the high ammonium concentrations than at the low ammonium concentrations for all species except summer Ulva sp.; higher growth of Hincksia sordida and Ulva sp. during winter than in summer but higher growth of Polysiphonia decipiens in summer compared to winter; and generally higher growth of $H$. sordida and Ulva sp. than of $P$. decipiens.

\section{Critical tissue- $\mathbf{N}$ concentrations}

Maximum tissue- $\mathrm{N}\left(N_{\max }\right)$ represents the maximum field tissue- $\mathrm{N}$ contents of algae used in experiments and not the maximum achieved under experimental conditions (Table 4). This concentration is used as it attempts to represent what is achievable under field situations. Critical $N$ contents $\left(N_{\mathrm{c}}\right)$ were highest during winter for Polysiphonia decipiens (28.8 $\mathrm{mg} \mathrm{N} \mathrm{g}^{-1}$ dry wt) but similar between winter and summer for Hincksia sordida (20.8 and $21.2 \mathrm{mg} \mathrm{N} \mathrm{g}^{-1}$ dry wt respectively). Only winter values of $N_{\mathrm{C}}$ could be calculated for Ulva sp. (mean $=27.5 \mathrm{mg} \mathrm{N} \mathrm{g}^{-1}$ dry wt) due to low summer growth (Table 4$)$. The subsistence quota $\left(N_{\mathrm{q}}\right)$ of all the species investigated did not vary between seasons, but $N_{\mathrm{q}}$ was lower for $H$. sordida compared to $P$. decipiens and Ulva sp. in winter. $N_{\mathrm{q}}$ could not be calculated for Ulva sp. in summer because of the absence of a relationship between growth and tissue-N (Table 4).

\section{Nitrogen storage and requirements}

The amount of $\mathrm{N}$ stored in excess of the critical limit $\left(N_{\mathrm{s}}=N_{\max }-N_{\mathrm{c}}\right)$ varied among species, with the lowest values observed during summer in Hincksia sordida (4.2 $\mathrm{mg} \mathrm{N} \mathrm{g}^{-1}$ dry wt) and the highest in winter (31.5 $\mathrm{mg} \mathrm{N} \mathrm{g}^{-1}$ dry wt) (Table 4). Seasonal responses of $N_{\mathrm{s}}$ were the same for $H$. sordida and Polysiphonia decipiens with higher values found during winter. The tissue N-pool which could support N-limited growth $\left(N_{\text {red }}\right)$ did not differ between seasons for $H$. sordida but was higher for $P$. decipiens in winter (Table 4).

The $\mathrm{N}$ required to sustain maximum algal growth $\left(N_{\text {req }}=\mu_{\max } \times N_{\mathrm{c}}\right)$ varied seasonally for Hincksia sordida and Polysiphonia decipiens with higher values in summer (Table 5). $N_{\text {req }}$ also varied among species with lowest values found in winter $P$. decipiens $(1.41 \mathrm{mg} \mathrm{N}$ $\mathrm{g}^{-1}$ dry wt $\mathrm{d}^{-1}$ ) and highest in winter Ulva sp. (3.03 mg $\mathrm{N} \mathrm{g}^{-1}$ dry wt $\mathrm{d}^{-1}$ ).

The storage capacity $\left(t_{\max }\right)$, defined as the number of days that excess $\mathrm{N}\left(N_{\mathrm{s}}\right)$ could support maximum growth, was similar for Hincksia sordida and Polysiphonia decipiens in winter (9.9 and $9.1 \mathrm{~d}$ respectively) and in summer (1.6 and $3.9 \mathrm{~d}$ respectively). A relatively low $t_{\max }$ was observed in Ulva sp. (5.2 d) during winter 
Table 4. Maximum tissue- $\mathrm{N}\left(N_{\max }\right)$, critical $\mathrm{N}\left(N_{\mathrm{c}}\right)$, subsistence quota $\left(N_{\mathrm{q}}\right), \mathrm{N}$ pools in excess of that necessary for maximum growth $\left(N_{\mathrm{s}}\right)$, and $\mathrm{N}$ pools that allow reduced growth $\left(N_{\text {red }}\right)$. All values were obtained from laboratory experiments, except for $N_{\max }$ values which were derived from tissue- $\mathrm{N}$ contents of algae collected from the field. Values are means $(\mathrm{CI}), \mathrm{n}=4, \mathrm{in} \mathrm{mg} \mathrm{N} \mathrm{g}{ }^{-1}$ dry wt

\begin{tabular}{|c|c|c|c|c|c|c|c|c|c|c|}
\hline \multirow[t]{2}{*}{ Species } & \multicolumn{2}{|c|}{$N_{\max }$} & \multicolumn{2}{|c|}{$N_{\mathrm{c}}$} & \multicolumn{2}{|c|}{$N_{\mathrm{q}}$} & \multicolumn{2}{|c|}{$N_{\mathrm{s}}\left(N_{\max }-N_{\mathrm{c}}\right)$} & \multicolumn{2}{|c|}{$N_{\text {red }}\left(N_{\mathrm{c}}-N_{\mathrm{q}}\right)$} \\
\hline & Winter & Summer & Winter & Summer & Winter & Summer & Winter & Summer & Winter & Summer \\
\hline H. sordida & $\begin{array}{c}52.3 \\
(10.6)\end{array}$ & $\begin{array}{l}25.4 \\
(5.3)\end{array}$ & $\begin{array}{l}20.8 \\
(3.8)\end{array}$ & $\begin{array}{l}21.2 \\
(1.7)\end{array}$ & $\begin{array}{c}8.8 \\
(1.4)\end{array}$ & $\begin{array}{l}11.4 \\
(1.2)\end{array}$ & 31.5 & 4.2 & 10.3 & 9.8 \\
\hline P. decipiens & $\begin{array}{l}45.0 \\
(5.6)\end{array}$ & $\begin{array}{l}33.2 \\
(2.1)\end{array}$ & $\begin{array}{l}28.8 \\
(2.0)\end{array}$ & $\begin{array}{l}23.5 \\
(2.4)\end{array}$ & $\begin{array}{l}12.5 \\
(1.9)\end{array}$ & $\begin{array}{l}11.7 \\
(1.3)\end{array}$ & 16.2 & 9.7 & 16.3 & 11.8 \\
\hline Ulva sp. & $\begin{array}{l}48.5 \\
(3.1)\end{array}$ & $\begin{array}{l}23.2 \\
(2.1)\end{array}$ & $\begin{array}{l}27.5 \\
(7.5)\end{array}$ & - & $\begin{array}{l}15.7 \\
(6.8)\end{array}$ & - & 21.0 & - & 12.8 & - \\
\hline
\end{tabular}

Table 5. Nitrogen requirements at maximum growth rates $\left(N_{\text {req }}=\mu_{\max } \times N_{\mathrm{c}}\right)$, storage capacity at non-limited growth $\left(t_{\max }\right)$, and the possible duration of reduced growth $\left(t_{\text {red }}\right)$ based on $N_{\text {red }}$ of 3 species of macroalgae from Port Phillip Bay. All values were obtained from laboratory experiments. Values are means, $\mathrm{n}=4$

\begin{tabular}{|c|c|c|c|c|c|c|}
\hline \multirow[t]{2}{*}{ Species } & \multicolumn{2}{|c|}{$\frac{N_{\max }}{\text { ng } \mathrm{N} \mathrm{g}^{-1} \text { dry wt d }{ }^{-1} \text { ) }}$} & \multicolumn{2}{|c|}{$-t_{\max }-$} & \multicolumn{2}{|c|}{$-t_{\text {red }} \longrightarrow$} \\
\hline & Winter & Summer & Winter & Summer & Winter & Summer \\
\hline Hincksia sordida & 1.93 & 2.46 & 9.9 & 1.6 & 18.6 & 10.7 \\
\hline Polysiphonia decipiens & 1.41 & 2.06 & 9.1 & 3.9 & 34.1 & 15.9 \\
\hline Ulva sp. & 3.03 & - & 5.2 & - & 11.4 & - \\
\hline
\end{tabular}

macroalgae that may have once inhabited these areas (Brown et al. 1980) to dominance by macroalgae with rapid nitrogen-uptake capacities, high surface to volume ratios and high turnover rates.

In most cases, ammonium-N was rarely depleted by the cultures of algae over the enrichment period, suggesting that only algae in the lowammonium treatments were undersupplied. However, the absence of saturated growth of Hincksia sordida suggests that this species may be able

(Table 5). The period of time over which algal growth could proceed at $\mathrm{N}$-limited rates $\left(t_{\text {red }}\right)$ was lowest in $H$. sordida and $P$. decipiens during summer (Table 5). During winter, N-limited or reduced growth rates could be supported for a relatively long period in $P$. decipiens (34.1 d) compared to H. sordida (18.6 d) and Ulva sp. (11.4 d). $t_{\text {red }}$ was lower in summer than winter, in both $H$. sordida (10.7 d) and P. decipiens (15.9 d).

\section{DISCUSSION}

The key finding of the present study was that all 3 species of macroalgae exhibited a high requirement for ammonium nitrogen at high concentrations. The good relationship between growth and tissue $\mathrm{N}$ for Hincksia sordida and Polysiphonia decipiens indicates a utilisation of $\mathrm{N}$ for growth. The experimental enrichment studies here suggest that in moderate to high nitrogen-enriched waters (i.e. 7.1 to $28 \mathrm{mM} \mathrm{NH}_{4}-\mathrm{N}$ ) these fast-growing macroalgae attain nutrient sufficiency and, as a consequence are able to colonise large areas of reef. The dominance of these fast-growing macroalgae at nearshore reefs in Port Phillip Bay is likely to represent a shift from slower growing to exploit even higher concentrations of $\mathrm{N}$ than those employed. The saturated growth (beyond 2 to $3 \%$ tissue-N content) in both Ulva sp. and Polysiphonia decipiens during winter suggests a capacity for $\mathrm{N}$ storage at high ammonium concentrations. Likewise, growth demands have been met at 2 to $3 \%$ tissue-N contents in other fast-growing ephemeral species (Pedersen \& Borum 1996, Fong et al. 1998). Differences in $\mathrm{N}$ usage between the 3 species examined were evident, with internal $\mathrm{N}$ reserves supporting reduced growth of $H$. sordida and Ulva sp. for shorter periods than $P$. decipiens. The ability of these 2 fast-growing algae to store $\mathrm{N}$ during non-limited growth was low when compared with $P$. decipiens. From September to February, low DIN availability would be insufficient to saturate N-uptake rates of these macroalgae (Campbell 1999), suggesting that $N$ could potentially limit macroalgal growth over this period if $\mathrm{N}$ uptake were directly coupled with growth. It would therefore appear that the rapid growth of these species under $\mathrm{N}$ enriched conditions and their prevalence in nearshore waters at certain times of the year is a direct indication of coastal eutrophication.

Comparisons between the estimated critical and subsistence tissue- $\mathrm{N}$ levels with field tissue nutrient data are useful to evaluate the nutrient supply and 
potential nutrient limitation of the 3 species. The relatively high tissue-N contents of Hincksia sordida and Polysiphonia decipiens collected from the field during winter, compared with N-enriched cultures in the laboratory, suggests that the growth of these 2 species may have been $\mathrm{N}$-limited even at the highest $\mathrm{N}$ concentrations supplied. This may lead to an underestimation of critical $\mathrm{N}\left(N_{\mathrm{c}}\right)$ and subsistence quotas $\left(N_{\mathrm{q}}\right)$ and may explain the comparatively low estimates calculated for $H$. sordida. The range of critical threshold limits of $\mathrm{N}\left(N_{\mathrm{c}}\right)$ (20.8 to $28.8 \mathrm{mg} \mathrm{g}^{-1}$ dry wt) of all the species examined are, however, comparable to those recorded for other macroalgae (e.g. Fujita et al. 1989, Pedersen \& Borum 1996). In winter, field tissue-N concentrations of the 3 species of macroalgae examined rarely fell below the critical or subsistence levels. Therefore, these algae are unlikely to be N-limited in winter. The relatively high winter $N_{\mathrm{c}}$ for $P$. decipiens is most likely associated with its reduced metabolism and growth during winter. During the austral summer, field tissue- $N$ concentrations of $H$. sordida fell below the critical $N_{\mathrm{c}}$ values, hence any additional supply of $\mathrm{N}$ at this time may lead to enhanced growth of $H$. sordida. 'Bloom' events are therefore likely to be dependent on moderate to high $\mathrm{N}$ availability and provide a direct indication of high nutrient richness in these coastal waters. The high $N_{\mathrm{q}}$ of Ulva sp. relative to P. decipiens and $H$. sordida also implies a high requirement for $\mathrm{N}$, and its prolific growth may also indicate high nutrient richness.

The lack of growth in N-replete Ulva sp. during summer is not entirely clear, but is likely to be a seasonal response whereby growth is uncoupled from physiological requirements and other factors such as temperature and light primarily control growth. Much of the $\mathrm{N}$ assimilated in this period may accumulate in nonphotosynthetic components (inorganic storage pools of $\mathrm{NH}_{4}{ }^{+}$and $\mathrm{NO}_{3}{ }^{-}$, nucleic acids and proteins) associated with cell regulation and respiration (McGlathery et al. 1996, McGlathery \& Pedersen 1999). A minor proportion of $\mathrm{N}$ is also most likely to be used in pigment synthesis, and this has been demonstrated by increased photosynthetic maxima $\left(P_{\max }\right)$ and pigment contents in these algae during winter (S.C. unpubl. data). This, however, is likely to constitute a small proportion of the total tissue-N (i.e. 2 to $3 \%$ ) as pigments represent only a small percentage of tissue- $\mathrm{N}$ in macroalgae (Rosenberg \& Ramus 1982, Duke et al. 1986).

The relative potential for nitrogen limitation of these macroalgae were evaluated by examining their demands for $\mathrm{N}$ at maximum growth rates. In summer, the $\mathrm{N}$ demands $\left(N_{\text {req }}\right)$ of Hincksia sordida and Polysiphonia decipiens were high because of their high growth rates during this time. In winter, the high requirements for $\mathrm{N}\left(N_{\text {req }}\right)$ by $H$. sordida and Ulva sp. relative to
$P$. decipiens also reflect high growth rates. In summer, the $N_{\text {req }}$ of $H$. sordida and $P$. decipiens would not be met by the nutrient supply through the uptake of ammonium; however, in winter, the $N_{\text {req }}$ of $P$. decipiens and Ulva sp. would be met by $\mathrm{N}$ uptake (Campbell 1999). In conjunction with the finding that tissue contents in $H$. sordida were below critical tissue levels (in summer) these findings suggest that growth is N-limited during summer. The range in $N_{\text {req }}$ for the 3 species in Port Phillip (1.4 to $3.0 \mathrm{mg} \mathrm{g}^{-1}$ dry wt $\mathrm{d}^{-1}$ ) are about 3- to 10-fold higher than reported for slow-growing species such as Sargassum baccularia (0.08 to $0.21 \mathrm{mg}$ $\mathrm{g}^{-1}$ dry wt d ${ }^{-1}$ ) (Schaffelke \& Klumpp 1998) and Ecklonia radiata ( 0.36 to $1.44 \mathrm{mg} \mathrm{g}^{-1}$ dry wt $\mathrm{d}^{-1}$ ) (Paling 1991). Accordingly, the $\mathrm{N}$ demands and high uptake rates of fast-growing species are likely to be very competitive with the demands of slower-growing macroalgae during high nutrient availability. This is indicated by the prolific abundance of small, ephemeral species at the site of study and the absence of large, structurally complex, slow-growing taxa (e.g. E. radiata).

The potential importance of internally stored $\mathrm{N}$ for algal growth in Port Phillip Bay was estimated from the amount of time during which algal growth could proceed at non-nutrient limited and reduced rates, assuming that no uptake of DIN occurred from the water. These estimates allow inter-species comparisons to be made, useful for describing their potential responses to periods of low $\mathrm{N}$ supply. The capacity of Hincksia sordida and Polysiphonia decipiens to mobilise stored $\mathrm{N}$ reserves to support non-limited growth was limited to shorter periods in summer algae than in winter algae. In summer $P$. decipiens would have a lower demand for $\mathrm{N}$ than $H$. sordida, evidenced by its 2-fold higher excess- $\mathrm{N}$ pool $\left(N_{\mathrm{s}}=9.7 \mathrm{mg} \mathrm{N} \mathrm{g}^{-1}\right.$ dry wt) compared to $H$. sordida (4.2 $\mathrm{mg} \mathrm{N} \mathrm{g}^{-1}$ dry wt). An opposite trend was apparent in winter, indicating of relatively fast growth and high $\mathrm{N}$ demands of $H$. sordida. Although this high demand for $\mathrm{N}$ may in part be due to higher laboratory temperatures $\left(15^{\circ} \mathrm{C}\right)$ relative to field temperatures $\left(10\right.$ to $\left.12^{\circ} \mathrm{C}\right)$, these demands are consistent with field observations of rapid growth in winter under saturating light (i.e. $>150 \mathrm{mmol} \mathrm{m}^{-2} \mathrm{~s}^{-1}$ ) (S.C. unpubl. data).

The $N_{\text {req }}$ and storage capacities of Ulva sp. appeared to differ markedly from those of the other species. Elevated winter $\mathrm{N}$ requirements of Ulva sp. were reflected by relatively high $N_{\mathrm{c}}, N_{\text {req }}, N_{\mathrm{s}}$ and $N_{\text {red }}$ and a low $t_{\text {max }}$ (5.2 d), indicating that most of the $\mathrm{N}$ pool in this species is used for growth, rather than being stored in winter. These findings are comparable to those of Fujita (1985), who found that stored N could support growth of Gracilaria tikvahiae for longer periods (14 d) than the faster-growing Ulva sp. (6 d) and Enteromorpha intestinalis (8 d), after which N-limited growth oc- 
curred. Pedersen \& Borum (1996) also reported similar time periods during which stores of $\mathrm{N}$ could support non-limited growth for Ceramium rubrum (2.3 d) and the chlorophytes Ulva lactuca (3.1d) and Cladophora sericea (3.4 d). In addition, U. lactuca has been shown to survive for shorter periods at reduced rates of growth $(6.5 \mathrm{~d})$ compared to other fast-growing algae such as Ceramium rubrum, Cladophora sericea and Chaetomorpha linum (8.7 to $10.1 \mathrm{~d}$ ) (Pedersen \& Borum 1996). The results of the present study also show that a shorter period of reduced growth could be supported by internal $\mathrm{N}$ reserves in Hincksia sordida and Ulva sp. (10.7 to 18.6 d) compared to Polysiphonia decipiens (15.9 to $34.1 \mathrm{~d})$. In conjunction with findings on nonlimited growth rates, it appears that of the 3 species examined, these 2 opportunistic species are most inclined to respond to high $\mathrm{N}$ availability with increased growth.

This study provides the first comparative account of $\mathrm{N}$ requirements and potential $\mathrm{N}$ storage capacities of fast-growing ephemeral macroalgae in south-eastern Australia. The high requirement for $\mathrm{N}$ and relatively low capacity for N storage by the opportunistic Hincksia sordida makes it susceptible to N-limitation in summer, when inputs of $\mathrm{N}$ to coastal waters are low. Ulva sp. also has a high requirement for $\mathrm{N}$ and a limited capacity to grow on stored reserves, its growth being dictated primarily by shifts in light and temperature. In contrast, Polysiphonia decipiens appears to have the capacity to store and survive on limited reserves of $\mathrm{N}$ for comparatively longer periods. The high nutrient demands and immediate use of $\mathrm{N}$ by these macroalgae suggests that they have a low capacity for buffering fluctuations in external nutrient concentrations. High nutrient inputs into nearshore waters sustain growth of these species and may increase their competitive potential at the expense of slower-growing macroalgae (e.g. Sargassum sp. and Ecklonia radiata), which grow in non-nutrient-enriched habitats in Port Phillip Bay. The growth and productivity of these fast-growing species are therefore important indicators of eutrophication in this nearshore marine system.

\section{LITERATURE CITED}

Allen SE (1989) Chemical analysis of ecological materials. Blackwell Scientific Publications, Oxford

American Public Health Association (1995) Standard methods for analysis of waters and wastewaters, 19th edn. American Public Health Association, Washington, DC

Björnsäter BR, Wheeler PA (1990) Effect of nitrogen and phosphorus supply on growth and tissue composition of Ulva fenestrata and Enteromorpha intestinalis (Ulvales, Chlorophyta). J Phycol 26:603-611

Brown VB, Rowan KS, Ducker SC (1980) The effects of sewage effluent on the macrophytes off Werribee, Port
Phillip Bay. Ministry for Conservation, Victoria, Environmental Studies Program, Task Report No. 273

Cambridge ML, Chiffings AW, Brittan C, Moore L, McComb AJ (1984) The loss of seagrass in Cockburn Sound, Western Australia. II. Possible causes of seagrass decline. Aquat Bot 24:269-285

Campbell SJ (1999) Uptake of ammonium by four species of macroalgae in Port Phillip Bay, Victoria, Australia. Mar Freshw Res 50:515-22

Chapman ARO, Craigie JS (1977) Seasonal growth in Laminaria longicruris: relation with dissolved inorganic nutrients and internal reserves of nitrogen. Mar Biol 40: $197-205$

Droop MR (1983) Some thoughts on nutrient limitation in algae. J Phycol 9:264-272

Duke CS, Lapointe BE, Ramus J (1986) Effects of light on growth, RuBPCase activity and chemical composition of Ulva species (Chlorophyta). J Phycol 22:362-370

Duke CS, Litaker W, Ramus J (1989) Effects of temperature, nitrogen supply and tissue nitrogen on ammonium uptake rates of the Chlorophyte seaweeds Ulva curvata and Codium decorticatum. J Phycol 25:113-120

Fong P, Boyer KE, Zedler JB (1998) Developing an indicator of nutrient enrichment in coastal estuaries and lagoons using tissue nitrogen content of the opportunistic alga, Enteromorpha intestinales (L. Link). J Exp Mar Biol Ecol 231: $63-79$

Fujita RM (1985) The role of nitrogen status in regulating transient ammonium uptake and nitrogen storage by macroalgae. J Exp Mar Biol Ecol 92:283-301

Fujita RM, Wheeler PA, Edwards RL (1989) Assessment of macroalgal nitrogen limitation in a seasonal upwelling region. Mar Ecol Prog Ser 53:293-303

Geertz-Hansen O, Sand-Jensen K (1992) Growth rates and photon yield of growth in natural populations of a marine macroalga Ulva lactuca. Mar Ecol Prog Ser 81:179-183

Hein M, Pedersen MF, Sand-Jensen K (1995) Size-dependent nitrogen uptake in micro- and macroalgae. Mar Ecol Prog Ser 118:247-253

Hurd CL, Dring MJ (1990) Phosphate uptake by intertidal algae in relation to zonation and season. Mar Biol 107: 281-289

Lapointe BE (1985) Strategies for pulsed nutrient supply to Gracilaria cultures in the Florida Keys: interactions between concentration and frequency of nutrient pulses. J Exp Mar Biol Ecol 93:211-222

Lapointe BE, O'Connell J (1989) Nutrient enhanced growth of Cladophora prolifera in Harrington Sound, Bermuda: eutrophication of a confined, phosphorus limited marine ecosystem. Estuar Coast Shelf Sci 28:347-360

Lapointe BE, Tenore KR (1981) Experimental outdoor studies with Ulva fasciata Delile. I. Interaction of light and nitrogen on nutrient uptake, growth and biochemical composition. J Exp Mar Biol Ecol 53:135-152

Larned ST, Stimson J (1996) Nitrogen-limited growth in the coral reef chlorophyte Dictyoshaeria carvernosa, and the effect of exposure to sediment derived nitrogen on growth. Mar Ecol Prog Ser 145:95-108

Lavery PS, McComb AJ (1991a) Macroalgal-sediment nutrient interactions and their importance to macroalgal nutrition in a eutrophic estuary. Estuar Coast Shelf Sci 32: 281-295

Lavery PS, McComb AJ (1991b) The nutritional eco-physiology of Chaetomorpha linum and Ulva rigida in Peel Inlet, Western Australia. Bot Mar 34:251-260

Light B, Woelkerling WJ (1992) Literature information review of benthic flora of Port Phillip Bay, Victoria, Australia. 
CSIRO (Tech Rep No. 6 Port Phillip Bay Environmental Study), Melbourne

Littler MM (1979) The effect of bottle volume, thallus weight, oxygen saturation levels and water movement on apparent photosynthetic rates in marine algae. Aquat Bot 7: 21-34

Lohman K, Priscu JC (1992) Physiological indicators of nutrient deficiency in Cladophora (Chlorophyta) in the Clark Fork of the Columbia River, Montana. J Phycol 28: 443-448

McGlathery KJ, Pedersen MF (1999) The effect of growth irradiance on the coupling of carbon and nitrogen metabolism in Chaetomorpha linum (Chlorophyta). J Phycol 35: 721-731

McGlathery KJ, Pederson MF, Borum J (1996) Changes in intracellular nitrogen pools and feedback controls on nitrogen uptake in Chaetomorpha linum (Chlorophyta). J Phycol 32:393-401

Paling EI (1991) The relationship between nitrogen cycling and productivity in macroalgal stands and seagrass meadows. PhD thesis, University of Western Australia, Perth

Pedersen MF, Borum J (1996) Nutrient control of algal growth in estuarine waters. Nutrient limitation and the importance of nitrogen requirements and nitrogen storage among phytoplankton and species of macroalgae. Mar Ecol Prog Ser 142:261-272

Pedersen MF, Borum J (1997) Nutrient control of estuarine

Editorial responsibility: Otto Kinne (Editor),

Oldendorf/Luhe, Germany algae: growth strategy and the balance between nitrogen requirements and uptake. Mar Ecol Prog Ser 161:155-163

Rosenberg G, Ramus J (1982) Ecological growth strategies in the seaweeds Gracilaria folifera (Rhodophyceae) and Ulva sp. (Chlorophyceae): soluble nitrogen and reserve carbohydrates. Mar Biol 66:251-259

Schaffelke B, Klumpp DW (1998) Nutrient limited growth of the coral reef macroalga Sargassum baccularia and experimental growth enhancement by nutrient addition in continuous flow culture. Mar Ecol Prog Ser 164:199-211

Sfriso A (1995) Temporal and spatial responses of growth of Ulva rigida C. Ag. to environmental and tissue concentrations in the Lagoon of Venice. Bot Mar 38:557-573

Strickland JDH, Parsons TR (1972) A practical handbook of seawater analysis, 2nd edn. Bull Fish Res Board Can 167:1-30

Valiela I, McClelland J, Hauxwell J, Behr PJ, Hersh D, Foreman K (1997) Macroalgal blooms in shallow estuaries: controls and ecophysiological and ecosystem consequences. Limnol Oceanogr 42(2):1105-1118

Wallentinus I (1984) Comparisons of nutrient uptake for Baltic macroalgae with different thallus morphologies. Mar Biol 80:215-225

Wheeler PA, Björnsäter BR (1992) Seasonal fluctuations in tissue nitrogen, phosphorus, and N:P for five macroalgal species common to the Pacific northwest coast. J Phycol 28:1-6

Submitted: November 29, 1999; Accepted: June 29, 2000 Proofs received from author(s): November 27, 2000 